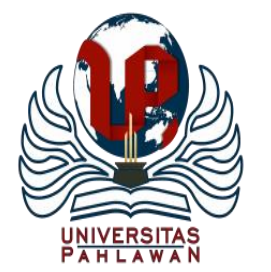

Jurnal Basicedu Volume 4 Nomor 4 Tahun 2020 Halm. 929 - 937

JURNAL BASICEDU

Research \& Learning in Elementary Education

https://jbasic.org/index.php/basicedu/index

\title{
Disrupsi Pendidikan IPA Sekolah Dasar dalam Menyikapi Merdeka Belajar dan Kampus Merdeka Menuju New Normal Pasca COVID-19
}

\author{
Muhammad Ilham Syarif ${ }^{1}$ \\ IAIN Batusangkar, Sumatera Barat, Indonesia \\ Email: mdilhamsf@gmail.com
}

\begin{abstract}
Abstrak
Merdeka belajar adalah kebijakan yang diterapkan oleh Kementrian Pendidikan dan Kebudayaan Indonesia. Merdeka belajar mendorong siswa untuk mampu berpikir literasi, numerasi dan berkarakter. Ketika pembelajaran dilaksanakan di rumah kebijakan merdeka belajar sudah mulai diterapkan. Hal ini juga mempengaruhi dalam kualitas pendidikan IPA. Namun Pelaksanaan merdeka belajar ketika pandemi masih terdapat kendala. Sehingga kebijakan merdeka belajar harus dievaluasi untuk disempurnakan. Tujuan artikel ini menganalisis disrupsi kebijakan merdeka belajar ketika pandemi untuk menyempurnaan menghadapi new normal pasca COVID-19. Metode peneliti yang digunakan adalah tinjauan pustaka atau literature research. Hasil penelitian ini menyimpulkan bahwa penerapan merdeka belajar merupakan kebijakan yang tepat dalam mempersipkan sumber daya manusia yang berkualitas dan berkarakter untuk zaman Revolusi Industri 4.0. Namun Indonesia masih mengalami permasalahan kendala dalam akses pembangunan yang belum merata seperti internet. Maka aritikel ini memberikan rekomendasi kepada pemegang kebijakan untuk penyebaran akses pembangunan dan melaksanakaan penelitian terhadap teknis pembelajaran merdeka belajar yang tepat untuk masing-masing daerah.
\end{abstract}

Kata kunci: isi, format, artikel. disrupsi; COVID-19, pendidikan IPA

\begin{abstract}
Free learning encourages students to be able to think about literacy, numeracy, and character. When Learning is implemented at home a free learning policy has begun to be applied. This also affects the quality of science education. However, the implementation of independent learning when there was an obstacle still occurred. So the policy of free learning must be evaluated to be perfected. The purpose of this article is to analyze the Disruption of the policy of independent learning when a pandemic is perfected to face the new normal after COVID-19. The research method used is a literature review or literature research. The results of this study conclude that the application of independent learning is the right policy in preparing quality human resources and character for the Industrial Revolution era 4.0. However, Indonesia is still experiencing problems with constraints in uneven development access such as the internet. Then this article provides recommendations for policyholders to disseminate access to development and conduct research on appropriate learning independent learning techniques for each region.
\end{abstract}

Keywords: disruption; COVID-19, natural sciences education

Copyright (C) 2020 Muhammad Ilham Syarif

$\triangle$ Corresponding author :

Address : IAIN Batusangkar

Email : mdilhamsf@gmail.com

ISSN 2580-3735 (Media Cetak)

Phone :

ISSN 2580-1147 (Media Online)

DOI : https://doi.org/10.31004/basicedu.v4i4.487 


\section{PENDAHULUAN}

Awal tahun 2020 dunia dikejutkan dengan terjadinya pandemi virus COVID-19, data terbaru 11 Juni 2020 sudah 7,446,229 orang terjangkit virus corona di seluruh dunia (corona data). Akibat pandemi corona ini tidak terlepas juga memberikan pengaruh terhadap ekonomi, sosial, dan pendidikan (Tufan \& Kayaaslan, 2020). 215 Negara dari seluruh dunia terpapar oleh virus COVID-19, sehingga Negara termasuk menerapkan kebijakan Worl From Home(WFH) (Abel \& McQueen, 2020;Tufan \& Kayaaslan, 2020). Hal ini juga diterapkan untuk pelaksanaan pembelajaran di sekolah untuk menekan penularan COVID-19. Menurut UNESCO 1.576.767.997 orang siswa terpaksa melaksankan pembelajaran di rumah, jumlah ini diprediksi akan terus meningkat karean persebaran COVID-19 masih terus berlangsung hingga sekarang (UNESCO, 2020).

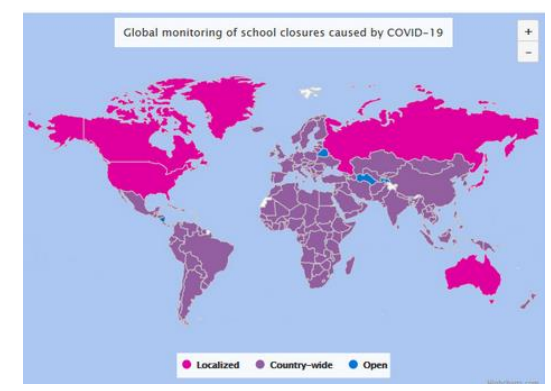

Gambar 1. Sebaran sekolah yang tutup karena COVID-19

Berdasarkan gambar di atas dapat kita simpulkan bahwa mayoritas sekolah di seluruh dunia sudah ditutup untuk mencegah menyebaran dari COVID-19. Kasus COVID-19 di Indonesia sudah mencapai 34,316 orang terdiri dari DKI Jakarta 8.503 orang, Jawa Timur 6.806 orang, Jawa Barat 2.448 orang, Sulawesi Selatan 2.383 orang,
Jawa Tengah 1.813 orang, Kalimantan Selatan 1.565 orang, Sematera Selatan 1.229 orang, Papua 1.137 orang, Banten 1.096 orang, Nusa Tenggara Barat 857 orang, Sumatera Barat 659 orang, Bali 640 orang, Sumatera Utara 635 orang, Sulawesi Utara 546 orang, Kalimantan Tengah 537 orang, Kalimantan Timur 362 orang, Maluku 328 orang, Sulawesi Tenggara 266 orang, Yogyakarta 250 orang, Kalimantan Barat 245 orang, Kepulauan Riau 228 orang, Maluku Utara 227, Papua Barat 191 orang, Kalimantan Utara 170 orang, Sulawesi Tengah 159 orang, Lampung 150 orang, Gorontalo 145 orang, Bangka Belitung 123 orang, Riau 120 orang, Nusa Tenggara Timur 105 orang, Jambi 105 orang, Sulawesi Barat 95 orang, Bengkulu 92 orang, Aceh 22 orang, lokasi tidak ditemukan 21 orang.

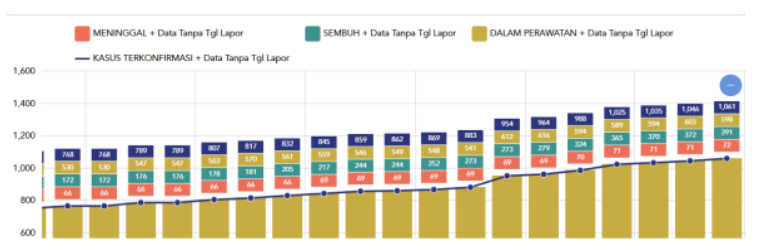

Gambar 2. Data penyebaran COVID-19

Berdasarkan gambar di atas dapat kita simpulkan bahwa penyebaran virus COVID-19, semakin meningkat. Walaupun pemerintah Indonesia sudah memberikan kebijakan persiapan Indonesia untuk memasukai fase New Normal (Ledoux \& Segniagbeto, 2020), New normal diberikan akses untuk masyarakat untuk memulai berkegiatan seperti biasa tetapi masih mengikuti protokoler kesehatan. Pada tanggal 7 juni 2020 sekolah sudah mulai di buka kembali. Kebijakan new normal ini diterapkan untuk melonggarkan kegiatan sosial manusia. Namun hal ini bukan 
jaminan bahwa virus COVID-19 berhenti menyebar.

Dengan kejadian COVID-19 manusia dipaksa untuk bisa berdaptasi secara cepat terhadap kondisi pandemi, seperti penggunakan teknologi pembelajaran, bekerja efektif dan efisien dirumah, dan berbagai hal lainnya (Huang et al., 2020;Azoulay, 2020). Hal ini juga berhubungan dengan kebijakan yang diterapkan oleh kementrian pendidikan tentang merdeka belajar dan kampus merdeka (Direktur Jenderal Pendidikan Tinggi, 2020).

Jika dianalisa maka akan terdapat hubungan yang erat terhadap kejadian pendemi ini terhadap pendidikan IPA yang dibutuhkan manusia di masa depan (Manalu, 2020). Hal ini juga sangat berpengaruh terhadap perkembangan sistem belajar IPA, seperti pemanfaatan teknologi dan ilmu alam. Namun berdasarkan evaluasi yang sudah peneliti lakukan ketika pandemi, maka terdapat beberapa hal yang perlu diperbaiki dan disempurnakan terhadap kebijakan merdeka belajar. Maka karena itu artikel ini akan membahas tentang Disrupsi Pendidikan IPA Menuju New Normal Pasca COVID-19.

\section{METODE}

Artikel ini akan meninjau dari berbagai sudut pandang tentang issue, situasi, kebijakan yang masih diperdebatkan (Triandini et al., 2019). Jenis metode peneitian ini adalah analisis kajian pustaka (literature research) (Pócza \& Dobos, 2018;Randolph, 2009;(Triandini et al., 2019). Penelitian ini akan memaparkan terhadap analisis jurnal ilmiah yang korelasi dengan pembahasan yang sudah dipilih. Menururt (Triandini et al., 2019) mengemukakan Tahap- tahap dalam metode penelitian ini adalah (1) memilih artikel, (2) mengumpulkan data awal, (3) tantangan dari topik, (4) mengumpulkan data pendukung, dan (5) menghasilkan kesimpulan dan rekomendasi outline. Hal ini menjadi metode yang dilakukan dalam menganalisis data dalam artikel ini.

\section{HASIL DAN PEMBAHASAN}

\section{Disrupsi}

Disrupsi adalah sebuah inovasi yang akan menggantikan seluruh sistem lama dengan cara-cara baru. Disrupsi berpotensi menggantikan pemain-pemain lama dengan yang baru (Ghufron, 2018). Disrupsi menggantikan teknologi lama yang serba fisik dengan teknologi digital yang menghasilkan sesuatu yang benar-benar baru dan lebih efisien, juga lebih bermanfaat.

Tips bagaimana cara Anda bisa menghadapi era disrupsi seperti sekarang (Oey-gardiner, 2018):

a. Meningkatkan Kualitas Sumber Daya Manusia (SDM)

Dengan pesatnya perubahan lini kehidupan menjadi serba digital, bukan tidak mungkin robot akan menggantikan pekerjaan manusia. SDM sebaiknya didorong untuk terus belajar dan meningkatkan pengetahuannya mengenai teknologi, karena teknologi sangat dibutuhkan dalam meningkatakn kualitas berbagai bidang yang dikembangkan.

b. Melakukan Inovasi 
Memiliki cara berpikir yang berbeda sehingga mampu membuat terobosan baru atau penyesuaian pada bisnis agar lebih sesuai dengan era disrupsi.

c. Adopsi Teknologi Digital

Perusahaan mampu menggunakan teknologi digital seperti Big Data, Autonomous Robots, Cybersecurity, Cloud, dan Augmented Reality. Ini sebagai perwujudan dari tiga solusi pintar dalam menghadapi Revolusi Industri 4.0, smart foundation, smart process, dan smart connectivity.

d. Bersiap Menghadapi Perubahan

Mengubah pola pikir dan memiliki kesadaran untuk lebih cepat dalam mengadaptasi perubahan. Seluruh karyawan dalam organisasi harus cepat beradaptasi dengan perubahan, karena efek disrupsi dapat mengubah segala hal, termasuk budaya organisasi dalam melakukan proses bisnisnya.

\section{Kebijakan Kemetrian Pendidikan dan} Kebudayaan (Kemendikbud)

a. Merdeka Belajar (Sekolah)

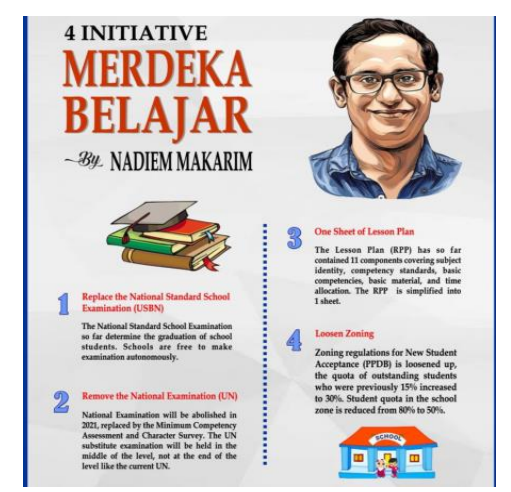

Gambar 3. Kebijakan Merdeka Belajar
Apa itu program "Merdeka Belajar" Inilah penjelasan Mendikbud Nadiem (Direktur Jenderal Pendidikan Tinggi, 2020).

1) USBN Diganti Ujian

Menurut Nadiem, situasi saat ini USBN membatasi penerapan dari semangat UU Sisdiknas yang memberikan keleluasaan bagi sekolah untuk menentukan kelulusan. Untuk arah kebijakan barunya, Tahun 2020 USBN akan diganti dengan ujian yang diselenggarakan hanya oleh sekolah. Nantinya, ujian dilakukan untuk menilai kompetensi siswa. Dimana ujian dalam bentuk tes tertulis dan atau bentuk penilaian lain yang lebih komprehensif. Seperti portofolio dan penugasan (tugas kelompok, karya tulis dan sebagainya). Dengan begitu, guru dan sekolah lebih merdeka dalam menilai hasil belajar siswa. Bahkan diharapkan anggaran USBN dialihkan untuk mengembangkan kapasitas guru dan sekolah guna meningkatkan kualitas pembelajaran.

2) 2021 UN diganti

Menteri Nadiem melihat situasi saat ini materi UN terlalu padat sehingga siswa dan guru cenderung menguji penguasaan konten, bukan kompetensi penalaran. Disamping itu, UN dianggap jadi beban siswa, guru dan orangtua karena menjadi indikator keberhasilan siswa sebagai individu. Karenanya tahun 2020, UN akan dilaksanakan terakhir kalinya. Sebagai penggantinya, pada 2021, UN diubah menjadi Asesmen Kompetensi Minimum 
dan Survei Karakter. Asesmen tersebut tidak dilakukan berdasarkan mata pelajaran atau penguasaan materi kurikulum seperti yang diterapkan dalam ujian nasional selama ini, melainkan melakukan pemetaan terhadap dua kompetensi minimum siswa, yakni dalam hal literasi dan numerasi. Asesmen ini dilakukan pada siswa di tengah jenjang sekolah (misalnya kelas 4, 8, 11). Arah kebijakan baru ini juga mengaju pada praktik baik pada level internasional seperti PISA dan TIMSS.

3) RPP dipersingkat

Rencana Pelaksanaan Pembelajaran (RPP) selama ini, guru diarahkan mengikuti format RPP secara kaku. Tetapi nanti guru akan bebas memilih, membuat, menggunakan dan mengembangkan format RPP. Dulu, RPP terlalu banyak komponen dan guru diminta menulis sangat rinci (satu dokumen RPP bisa lebih 20 halaman). Tetapi nanti akan dipersingkat yakni RPP berisi tujuan pembelajaran, kegiatan pembelajaran dan asesmen. RPP hanya 1 halaman saja. Sehingga penulisan RPP dilakukan dengan efisien dan efektif yang menjadikan guru punya waktu untuk mempersiapkan juga mengevaluasi proses pembelajaran itu sendiri.

4) Zonasi PPDB lebih fleksibel

Untuk program Merdeka Belajar yang terrakhir ini, Nadiem menjelaskan bahwa Kemendikbud tetap menggunakan sistem zonasi dalam Penerimaan Peserta Didik Baru (PPDB). Adapun kebijakannya, PPDB lebih fleksibel untuk mengakomodasi ketimpangan akses dan kualitas di berbagai daerah. Menurut Nadiem, komposisi PPDB jalur zonasi dapat menerima siswa minimal 50 persen, jalur afirmasi minimal 15 persen, dan jalur perpindahan maksimal 5 persen. Untuk jalur prestasi atau sisa 0-30 persen lainnya disesuaikan dengan kondisi daerah. "Daerah berwenang menentukan proporsi final dan menetapkan wilayah zonasi," ujar Nadiem.

b. Kampus Merdeka

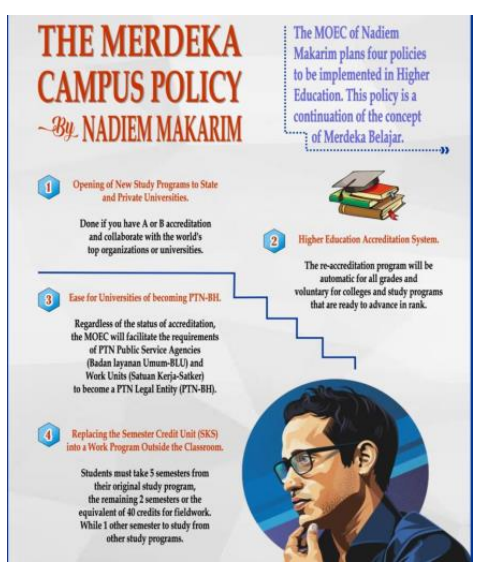

Gambar 4. Kebijakan Kampus Merdeka

Apa itu program Kampus Merdeka? Inilah penjelasan Mendikbud Nadiem (Kemendikbud, 2020).

1) Pembukaan program studi baru

Perguruan tinggi diberikan kebebasan dalam membuka programstudi secara mandiri. Perguruan Tinggi tersebut memiliki akreditasi A dan B. Kemudian Prodi dapat diajukan jika ada kerjasama dengan mitra perusahaan, organisasi 
nirlaba, institusi multilateral, atau universitas Top 100 ranking QS. Hal ini dilakukan untuk mempermuda dan memperbesar akses peluang lapangan kerja (Direktur Jenderal Pendidikan Tinggi, 2020).

2) Sistem akreditasi perguruan tinggi Akreditasi yang sudah ditetapkan oleh BAN-PT teap berlaku selama 5 tahun dan akan diperbarui secara otomatis. Perguruan tinggi yang terakreditasi $\mathrm{V}$ atau $\mathrm{C}$ dapat mengajukan kenaikan kapanpun secara sukarela. Kemudian Tracer Study wajib dilakukan setiap tahun (Direktur Jenderal Pendidikan Tinggi, 2020).

3) Perguruan tinggi negeri berbadan hukum Perguruan tinggi badan Bukum (BH) dipermudah bagi PTN BLU dan Satker. PTN BLU dan Satker mengajukan perguruan tingginya untuk menjadi $\mathrm{BH}$ tanpa ada akreditasi minimum. PTN dapat mengajukan permohonan BH kapanpun apabila merasa sudah siap.

4) Hak belajar tiga semester di luar program studi

Perguruan tinggi wajib memberikan hak bagi mahasiswa untuk sukarela dapat memilih mengambil SKS diluar perguruan tinggi 2 semester dan ditambah lagi 1 semester di prodi lain di PT yang sama. Setiap sks di artikan jam kegiatan bukan jam belajar. Definisi kegiatan adalah praktik kerja (magang), pertukaran pelajar, proyek di desa, wirausaha, riset, studi independen, dan kegiatan mengajar di daerah terpencil. Semua harus sesuai dibimbing dosen.

\section{New Normal}

Definisi new normal adalah skenario untuk mempercepat penanganan COVID-19 dalam aspek kesehatan dan sosial-ekonomi. Pemerintah Indonesia telah mengumumkan rencana untuk mengimplementasikan skenario new normal dengan mempertimbangkan studi epidemiologis dan kesiapan regional. Penerapan new normal akan sangat berpengaruh terhadap kebiasan-kebiasan baru masyarakat (Bryant \& Elofsson, 2020).

Kementerian Kesehatan (Kemenkes) menerbitkan Keputusan Menteri Kesehatan nomor HK.01.07/MENKES/328/2020 tentang Panduan Pencegahan dan Pengendalian COVID-19 di Tempat Kerja Perkantoran dan Industri dalam Mendukung Keberlangsungan Usaha pada Situasi Pandemi. Menteri Kesehatan Terawan Agus Putranto mengatakan dunia usaha dan masyakat pekerja memiliki kontribusi besar dalam memutus mata rantai penularan karena besarnya jumlah populasi pekerja dan besarnya mobilitas, serta interaksi penduduk umumnya disebabkan aktivitas bekerja. "Tempat kerja sebagai lokus interaksi dan berkumpulnya orang merupakan faktor risiko yang perlu diantisipasi penularannya," katanya, seperti dikutip situs web Kemenkes. Peraturan Pemerintah nomor 21 Tahun 2020 tentang Pembatasan Sosial Berskala Besar (PSBB) dalam rangka percepatan penanganan COVID-19 telah menyatakan, PSBB dilakukan salah satunya 
dengan meliburkan tempat kerja. Namun dunia kerja tidak mungkin selamanya dilakukan pembatasan, roda perekonomian harus tetap berjalan. "Untuk itu pasca pemberlakuan PSBB dengan kondisi pandemi COVID-19 yang masih berlangsung, perlu dilakukan upaya mitigasi dan kesiapan tempat kerja seoptimal mungkin sehingga dapat beradaptasi melalui perubahan pola hidup pada situasi COVID-19 atau New Normal," ujarnya(Lau et al., 2020).

\section{COVID-19}

Virus corona (severe acute respiratory syndrome coronavirus 2 (SARS-CoV-2) adalah virus yang menyerang sistim pernapasan. Virus ini menginfeksi sistem pernapasa gejalanya seperti infeksi paru-paru yang berat, hingga kematian (WHO, 2020). Severe acute respiratory syndrome coronavirus 2 (SARS-CoV-2) yang lebih dikenal dengan nama virus Corona/COVID-19 adalah jenis baru dari coronavirus yang menular ke manusia. Walaupun lebih banyak menyerang lansia, virus ini sebenarnya bisa menyerang siapa saja, mulai dari bayi, anakanak, hingga orang dewasa, termasuk ibu hamil dan ibu menyusui (Health, 2020).

Infeksi virus Corona disebut COVID-19 (Corona Virus Disease 2019) dan pertama kali ditemukan di kota Wuhan, China pada akhir Desember 2019. Virus ini menular dengan sangat cepat dan telah menyebar ke hampir semua negara, termasuk Indonesia, hanya dalam waktu beberapa bulan (Li et al., 2020). Hal tersebut membuat beberapa negara menerapkan kebijakan untuk memberlakukan lockdown dalam rangka mencegah penyebaran virus Corona. Di Indonesia sendiri, diberlakukan kebijakan Pembatasan Sosial Berskala Besar (PSBB) untuk menekan penyebaran virus ini dan menetapkan kebijakn work form home (WFH) untuk mengontrol penularan penyebaran virus COVID-19 (Wajdi et al., 2020).

Pada tahun 2020 seluruh dunia dikejutkan dengan terjadinya pandemi virus COVID-19. Hampir seluruh aspek kehidupan manusia terpapar oleh virus COVID-19 termasuk pendidikan. Adanya COVID-19 untuk memaksa manusia untuk segera merubah kebiasaan kehidupannya dari kebiasaan yang normal. Berdasarkan hasil wawancara dengan siswa, guru, dosen dan masyarakat. Peneliti menemukan data yang bermuara kepada satu ide yaitu digitalitasasi kehidupan manusia termasuk dalam bidang pendidikan (Suwardana, 2018). Namun digitatalisasi saja, tanpa memperhatikan faktor kemanusiaan maka tujuan pendidikan tidak tercapai.

Kebijakan merdeka belajar yang akan diterapkan secara utuh oleh mentri pendidikan pada tahun 2021, sudah mulai diterapkan oleh pemerintah,karena darurat pandemi. Pandemi COVID-19 ini membuka wawasan kita seperti sumber daya manusia (SDM) seperti apa yang dibutuhkan oleh masa depan, pendidikan yang cocok untuk era Revolusi Industri 4.0 dan Society 5.0, dan gaya hidup manusia yang cocok untuk masa depan. 
Kebijakan merdeka belajar yang terdiri dari empat poin sudah mulai diterapkan oleh pemerintah, seperti kebijakan menghapusan Ujian Nasional (UN) yang akan direncakan pada tahun 2021, ternyata sudah dilaksanakan pada tahun 2020 ini. UN sebagai standar kelulusan sekolah tidak cocok untuk kebutuhan SDM pada saat ini. Soal-soal UN yang cenderung hanya bersifat hafalan tidak representatif terhadap kebutuhakn SDM saat ini. UN diangggap hanya sebagai beban untuk orangtua, siswa dan guru untuk mengejar target kelulusan saja, bukan sebagai keahlian yang perlu dikuasai oleh siswa. Kemudian USBN diganti dengan bentuk assessment yang terdiri dari kemampuan literasi, numerasi dan karakter. Hal ini sangat dibutuhkan oleh SDM saat ini. Berdasarkan hasil penelitian PISA pada tahun 2018 Indonesia mendapat urutan 71 dari 77 negara (OECD, 2019). Hal ini sesuai dengan perilaku yang dilakukan oleh warga Negara Indonesia. Warga Negara Indonesia mengetahui cara hidup bersih dan mencegah penularan virus, namun warga negara Indonesia tidak melaksanakannya. Hal ini terjadi karena budaya literasi Indonesia masih rendah. Pengetahuan hanya bersifat teori bukan bersifat penerapan yang harus dilakukan dalam kehidupuan sehari-hari.

Literasi adalah kebudayaan penerapan ilmu pengetahuan yang dimiliki oleh manusia (Dinni, 2018). Terdapat banyak jenis literasi yang harus diterapkan dalam kehidupan seperti budaya literasi teknologi, literasi sains, literasi ekonomi dan lainya. Ketika diterapkan kebijakan Work Form Home (WFH). Warga negara cenderung bergerak pasif dan tidak produktif karena tidak terbiasa literasi teknologi. Hal ini membuka wawasan kita bahwa teknologi adalah bekal penting yang perlu dimiliki oleh manusia. Teknologi juga sangat dibutuhkan dalam bidang pendidikan, seperti seorang guru harus mampu memilih alat yang tepat untuk pembelajarannya seperti:

a. Smart class

Sebuah aplikasi yang diluncurkan oleh pemerintah untuk membantu pengajaran dan pembelajaran. Aplikasi smart class dapat di akses dimanapun dan kapanpun ketika siswa dan guru online.

b. Zenius

Sebuah platform yang dikembangkan untuk mempersiapkan siswa untuk UN dan UTBK. Zenius ini juga menyediakn kelas online yang terdiri 12 orang dan memiliki try out setiap minggunya

c. Quiper

d. Google Indonesia

e. Ruang Guru

f. TVRI

Selain menetapkan kebijakan merdeka belajar, kemendikbud juga menetapkan kebijakan kampus merdeka yang terdiri empat kebijakan yaitu:

a. Pembukaan program studi

b. Sistem akreditasi perguruan tinggi

c. Perguruan tinggi berbadan hukum

d. Hak belajar tiga semester di luar peguruan tinggi 
Kebijakan hak belajar di luar jurusan yang dipilih sangat relevan dengan kebutuhan SDM zaman ini. Seperti kita lihat ketika WFH bahwa seorang guru harus menguasai teknologi dalam mempermudah akses belajarnya. Guru harus memiliki ide kreatif dalam mengembangkan metode pembelajarannya, seperti penggunaan video, youtube dan aplikasi lainnya.

Kebijakan merdeka belajar dan kampus merdeka merupakan sebuah inovasi dalam pendidikan Indonesia. Namun kebijakan ini harus disempurnakan, seperti penggunaan teknologi dalam belajar hal itu sangat penting sekali dalam meningkatkan kualitas pendidikan Indonesia. Di sisi lain keadaan pemerataan pembangunan di wilayah Indonesia adalah sebuah tantangan yang harus di hadapi. Kuliah online yang ditetapkan sebagai kebijakan mencegah penularan COVID19 mengalami tantangan tidak terdapat sinyal di beberapa wilayah Indonesia.

Pendidikan IPA harus disesuiakan dengan perkembangan teknologi (Syofyan \& Ismail, 2018). Konsep pembelajaran IPA yang terdiri dari Fisika, Kimia, biologi, lingkungan dan IPBA. Perkembangan teknologi membantu manusia dalam mempermudah akses dalam pembelajaran, seperti penggunan daring dan luring (Alt, 2018). Sehingga dibutuhkan disrupsi dalam pembelajaran IPA. Disrupsi adalah sebuah inovasi yang akan menggantikan seluruh sistem lama dengan caracara baru (Rahardja et al., 2019). Disrupsi berpotensi menggantikan pemain-pemain lama dengan yang baru (Ghufron, 2018). Sehingga pembelajaran yang dahulu bersifat luring harus mengalami perkembangan dengan daring seperti penggunaan aplikasi Youtube, Sigil, Kinemaster, Google Meeting, Zoom dan WEBEX. Hal ini dilakukan untuk tercapainya efektif dan efisiensi dalam pembelajaran pada era new normal.

STEM merupakan sebuah pendekatan yang sering diperbincangkan dalam perkembangan Revolusi 4.0 dan Society 5.0. Hal ini membantu tujuan pendidikan tercapai. Manusia membutuhkan pembelajaran yang bersifat intergatif, seperti sains, matematika, teknik dan teknologi. Sehingga pembelajaran IPA yang bersifat konvensional harus ditinggalkan. Seperti penggunanan dominasi metode ceramah ataupun hanya bersifat membaca. Pembelajaran IPA yang dilakukan harus dipadukan dengan tenologi dan aplikatif dengan lingkungan sekitar seperti penggunaan mikroskop handphone.

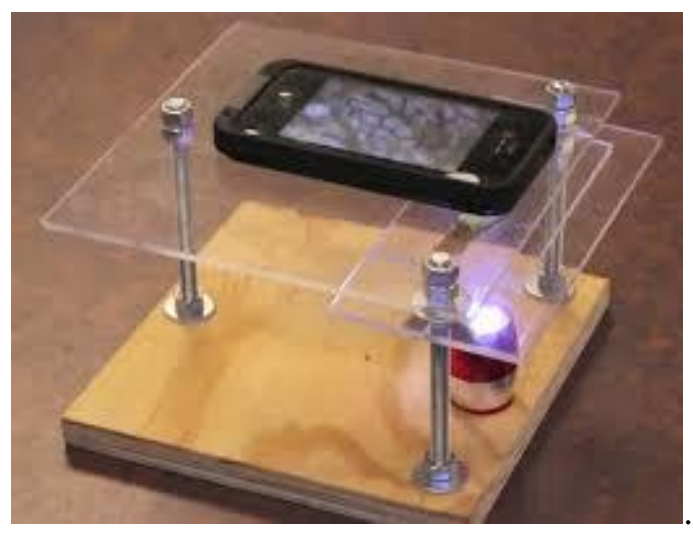

Gambar 5. Mikroskop Handphone

\section{SIMPULAN}

Pada tahun 2020 dunia mengalami permasalahan pandemi virus COVID-19. Hal ini membuat pengaruh besar terhadap kehidupan manusia, termasuk bidang pendidikan IPA. Digitalisasi pendidikan adalah tantangan besar yang 
harus dihadapi Indonesia. Namun Indonesia sudah memiliki kebijakan merdeka belajar dan kampus merdeka yang diterapkan oleh kemendikbud untuk menghadapi tantangan tersebut. Kampus merdeka memiliki empat kebijakan dan merdeka belajar memiliki empat kebijakan. Hal ini sudah diterapkan oleh pemerintah ketika Work Form Home (WFH). Namun Indonesia masih mengalami masalah dalam pembangunan yang belum merata, seperti sinyal internet yang belum tersebar merata. Berdasakan artikel ini maka peneliti merekomendasikan untuk pemegang kebijakan untuk bisa membantu mendukung kebijakan Pendidikan IPA dengan membantu menyebaran akses ke seluruh wilayah Indonesia dan mengadakan uji coba penelitian kelompok terbatas sebagai bahan evaluasi terhadap kebijkan kampus merdeka dan merdeka belajar.

\section{DAFTAR PUSTAKA}

Alt, D. (2018). Science teachers' conceptions of teaching and learning, ICT efficacy, ICT professional development and ICT practices enacted in their classrooms. Teaching and Teacher Education. https://doi.org/10.1016/j.tate.2018.03.020

Abel, T., \& McQueen, D. (2020). The COVID-19 pandemic calls for spatial distancing and social closeness: not for social distancing! In International journal of public health. https://doi.org/10.1007/s00038-020-01366-7

Azoulay, A. (2020). 290 million students out of school due to COVID-19: UNESCO releases first global numbers and mobilizes response. Https://En.Unesco.Org.

Bryant, P., \& Elofsson, A. (2020). Estimating the impact of mobility patterns on COVID-19 infection rates in 11 European countries. MedRxiv. https://doi.org/10.1101/2020.04.13.2006364 4

Dinni, H. N. (2018). HOTS ( High Order Thinking
Skills ) dan Kaitannya dengan Kemampuan Literasi Matematika. Prisma.

Direktur Jenderal Pendidikan Tinggi. (2020). Buku Panduan Merdeka Belajar - Kampus Merdeka. Direktorat Jenderal Pendidikan Tinggi Kementerian Pendidikan Dan Kebudayaan.

Ghufron, M. A. (2018). Revolusi industri 4.0: Tantangan, Peluang dan Solusi Bagi Dunia Pendidikan. Seminar Nasional Dan Diskusi Panel Multidisiplin Hasil Penelitian Dan Pengabdian Kepada Masyarakat.

Health, C. of A. as represented by the D. of. (2020). COVID-19, Australia: Epidemiology Report 5: Reporting week ending 19:00 AEDT 29 February 2020. COVID-19 National Incident Room Surveillance Team. Commun Dis Intell. https://doi.org/https://doi.org/10.33321/cdi.2 020.44 .20

Huang, R. H., Liu, D. J., Tlili, A., Yang, J. F., \& Wang, H. H. (2020). Handbook on facilitating flexible learning during educational disruption: The Chinese experience in maintaining undisrupted learning in COVID-19 Outbreak. In Smart Learning Institute of Beijing Normal University UNESCO.

Kemendikbud. (2020). Mendikbud Luncurkan Empat Kebijakan Merdeka Belajar: Kampus Merdeka. Kementerian Pendidikan Dan Kebudayaan.

Lau, H., Khosrawipour, V., Kocbach, P., Mikolajczyk, A., Schubert, J., Bania, J., \& Khosrawipour, T. (2020). The positive impact of lockdown in Wuhan on containing the COVID-19 outbreak in China. Journal of Travel Medicine. https://doi.org/10.1093/jtm/taaa037

Ledoux, B., \& Segniagbeto, K. (2020). What price will education pay for COVID-19?. UNESCO.

Li, J. W., Han, T. W., Woodward, M., Anderson, C. S., Zhou, H., Chen, Y. D., \& Neal, B. (2020). The impact of 2019 novel coronavirus on heart injury: A Systematic review and Metaanalysis. In Progress in Cardiovascular Diseases. 
https://doi.org/10.1016/j.pcad.2020.04.008

Manalu, W. B. (2020). KONSEP "MERDEKA BELAJAR": KEMANA ARAH PENDIDIKAN INDONESIA? Humas Unja.

OECD. (2019). PISA 2018 Results. In OECD Publishing.

Oey-gardiner, M. (2018). Tantangan Pendidikan Tinggi Indonesia di Era Disrupsi dan Globalisasi. Sdg Center Unpad.

Pócza, K., \& Dobos, G. (2018). Research methodology. In Constitutional Politics and the Judiciary: Decision-making in Central and Eastern Europe. https://doi.org/10.4324/9780429467097-2

Rahardja, U., Hidayanto, A. N., Hariguna, T., \& Aini, Q. (2019). Design Framework on Tertiary Education System in Indonesia Using Blockchain Technology. 2019 7th International Conference on Cyber and IT Service Management, CITSM 2019. https://doi.org/10.1109/CITSM47753.2019. 8965380

Randolph, J. J. (2009). A guide to writing the dissertation literature review. Practical Assessment, Research and Evaluation.

Syofyan, H., \& Ismail. (2018). Pembelajaran Inovatif Dan Interaktif Dalam Pembelajaran IPA Innovative And Interactive in Science Learning. Media Pengabdian Kepada Masyarakat.

Suwardana, H. (2018). Revolusi Industri 4. 0 Berbasis Revolusi Mental. JATI UNIK: Jurnal Ilmiah Teknik Dan Manajemen Industri. https://doi.org/10.30737/jatiunik.v1i2.117

Triandini, E., Jayanatha, S., Indrawan, A., Werla Putra, G., \& Iswara, B. (2019). Metode Systematic Literature Review untuk Identifikasi Platform dan Metode Pengembangan Sistem Informasi di Indonesia. Indonesian Journal of Information Systems. https://doi.org/10.24002/ijis.v1i2.1916

Tufan, Z. K. O. Ç. A. K., \& Kayaaslan, B. (2020). Crushing the curve, the role of national and international institutions and policy makers in covid-19 pandemic. In Turkish Journal of
Medical

Sciences. https://doi.org/10.3906/sag-2004-167

UNESCO. (2020). COVID-19 Educational Disruption and Response. Unesco.Org.

Wajdi, M. B. N., Iwan Kuswandi, Umar Al Faruq, Zulhijra, Z., Khairudin, K., \& Khoiriyah, K. (2020). Education Policy Overcome Coronavirus, A Study of Indonesians. EDUTEC: Journal of Education And Technology.

https://doi.org/10.29062/edu.v3i2.42

WHO. (2020). Novel Coronavirus (COVID-19) Situation. Who.

https://www.worldometers.info/coronavirus/ 